\title{
The Current Practices of Instructional Supervision Approaches and Teachers' Professional Development in Secondary Schools of Bale Zone of Oromia Region
}

\author{
Fekadu Dechassa \\ College of Education and Behavoral Studies, Madda Walabu University, PO box247, Bale-Robe, Ethiopia
}

\section{The research is financed by Haramaya University}

\section{Abstract}

The purpose of the study is to investigate the current practices of instructional supervision approaches in secondary schools of Bale Zone. The study particularly focuses on the practices and contributions of instructional supervision approaches, and the factors affecting their implementation in promoting teachers professional development. The study has employed a descriptive survey design, which was supplemented by qualitative research to enrich quantitative data. Data were gathered from nine randomly selected secondary schools in Bale Zone. The respondents included 182(52.8\%) teachers were selected using systematic random sampling technique. In addition 54 instructional supervision committee members were included in the study. All nine principals and, eight secondary school supervisors had participated. Questionnaire was the main instrument of data collection supplemented with interview method. Frequency, percentage, and chi-square analysis were employed to analyze the data. While the qualitative data obtained through interview was analyzed using descriptive narrative method. The results of the study reveal that the practices of instructional supervision approaches and their contribution to teachers' professional development were low. Instructional supervisors were found to get involved in the difficult task of supervision without having prior trainings, and their contributions were also unsatisfactory in promoting professional development of teachers. Furthermore, the study shows that: lack of trained supervisors, lack of supervision manuals, lack of training, shortage of budget, and high teaching load of supervisors and assignment of small number of supervisors hinder proper implementation of instructional supervision. As a result, awareness on the part of instructional supervisors and teachers through seminars, workshops and discussion forums about the different approaches of supervision in order to bring professional growth of teachers and improving their instructional practices were recommended. Moreover, suggestions were forwarded to solve the factors that hinder proper implementation of instructional supervision practices.

Keywords: instructional supervision, Teachers professional development, Supervision approach

DOI: $10.7176 /$ RHSS/9-9-01

Publication date:May $31^{\text {st }} 2019$

\section{INTRODUCTION}

\subsection{Heading 2}

\subsection{Background of the Study}

Schools are the formal agencies of education where the future citizens are shaped and developed through the process of teaching and learning. So schools need to help all students to develop their potentials to the highest level. This requires the effectiveness and commitment of the stakeholders particularly teachers, school leaders and management (Aggarwal, 1985). So schools have to improve their basic functions of teaching and learning process that aims at helping and empowering all students to raise their broad outcomes through instructional improvement.

To achieve these expected outcomes, education system must ensure the existence of relevant curriculum; and improved instructional situations and professionally motivated and competent teachers. In line with this, Mohanty (1990) stated that in educational system, there are different variables that have their own contribution for its development. Of all, the one which is the main input and important is the teacher who needs effective instructional support. The relevant and quality education can be provided for the learners by engaging a welltrained and professionally developed teacher at all levels of education.

In line with this Ahmed (1998) mentioned that the effectiveness and efficiency of an organization are relied on the quality of performance of the staff. Schools are within the dynamic and changing social system, teachers and other staff personnel continually face new and challenging situation every time. Thus teachers have great need to get appropriate supervisory support to become professionally competent.

Effective learning of students is promoted through the provision of effective supervisory support to teachers. In support of the above idea, Chanyalew (2005) stated that instructional supervision approaches are important in promoting teachers professional development as they are frequently designed to identify and exemplify various effective classroom techniques and teacher skill to promote better teaching and learning. Similarly, Supervision Manual of MoE (1987) illustrated the role of supervision in school system as ensuring curriculum 
implementation, providing direct technical support to teachers, providing on job training to teachers, conducting formative education program evaluation, monitoring and evaluation. School-based instructional supervision is focusing mainly on the total school improvement and quality of education provided for the learner. Supporting this, MoE (1995) mentioned that the main focus of supervision became providing support for teachers and enhances their role as key professional decision makers in practice of teaching.

It is believed that the improvement of schools would not be accomplished without improving teachers' education. The quality of teachers' education is determined by the provision of adequate supervision support from teachers. The realization of professional competence of teachers and the quality of education remains questionable unless due emphasis is given from education officials at different levels to implement instructional supervision effectively. Therefore, the concern of this study is to see the current practice of instructional supervision approaches and factors affect this practice.

\subsection{Statement of the Problem}

Over a long period of time supervision had been based on hierarchical principles. The role of the teacher was to impart basic truths to children, whereas the role of the supervisor was to serve as the "inspector" to ensure the curriculum had been followed and essential skills were learned (Ebmeier and Nicklaus, 1999). As this orientation toward teacher supervision became more common, many teachers were afraid to ask supervisors for help or to seek collegial assistance for fear that doing so would expose weaknesses in their teaching, which could be reflected later in low evaluations and possible punitive actions. As Ebmeier and Nicklaus (1999) noted, supervision as an evaluation tool reduced the possibility of nurturing collegiality, collaboration, and reflective practice.

In the current practice, instructional supervision approaches supposed to focus mainly on teachers' professional growth so as to enhance instructional practice of schools and to bring about the desired change of behavior on the parts of their students. As stated by Carron, De Grauwe and Govinda (1998), education systems rely on instructional supervision to control and improve instruction by improving the quality of teachers and the achievement of learners. And educational supervision has greater potential force to enhance teachers' professional efficiency there by contributing to students learning better.

However, from experience of the researcher, the existing reality of supervision in the secondary schools of Bale Zone does not seem to suggest a positive impact of supervision approaches on instructional improvement. It is heard from some secondary school teachers that they do not receive what they except from supervisors, supervisors often not seen in schools. Being remote figures without realistic connections with the reality of the classroom, they usually engage in routine inspection of administrative nature. As Chanyalew(2005) illustrated, many teachers have been heard complaining that conferences andworkshops at grassroots level are nonexistent. Moreover, teachers are not benefiting fromsupervisors. Thus, teachers face difficulties not only in tackling instructional problems but also in implementation of curriculumand new instructional approaches.

As far as the practice of instructional supervision in primary and secondary schools is concerned, some researches were conducted a research in different regions. For instance Haile (2006) conducted a study on supervisors' techniques, Chanyalew (2005) on supervisory procedures, and Atiklt (2008) on major functions of supervision. Almost all of the above studies found that supervisory techniques, procedures and skills of supervisors are inefficient to improve the quality of teachers and the achievement of learners. Furthermore, supervisors are not putting the necessary effort in providing in-service training to enhance teachers' effectiveness. But the study did not address the practice and contribution of instructional supervision approaches for promoting teachers' professional development.

To the knowledge of the researcher, there is no sufficient studies were addressed the practice and contributions of instructional supervision approaches for promoting teachers' professional development in Bale Zone. Due to this, the researcher decided to fill the gap by conducting research in Bale Zone. Therefore, the main purpose of the study is to assess the contribution, the current practice, the instructional supervision approach preferred by teachers and factors hindering instructional supervision approaches for teachers' professional development in secondary schools of Bale Zone.

To these end, the following basic questions raised to answer in the course of the study.

1. To what extent do instructional supervision approaches being practiced by the instructional supervisors in secondary schools of Bale Zone?

2. To what extent are instructional supervision approaches contributing to teachers' professional development in secondary schools of Bale Zone?

3. What type of supervisory approach do teachers prefer in secondary schools of Bale Zone?

4. What are the major factors hindering the practice of instructional supervision helpful to teachers professional development in secondary schools of Bale Zone? 


\subsection{Objectives of the Study General Objectives}

The general objective of this study was to assess the contribution, practice of school based instructional supervision approaches and factors hindering the practice of instructional supervision and secondary school teachers' professional development.

\section{Specific Objectives}

More specifically, the objectives of this study were to:

1. Examine the extent of instructional supervision approaches being practiced by the instructional supervisors in secondary schools of Bale Zone.

2. Assess the contribution of instructional supervision approaches for teachers' professional development in secondary schools of Bale Zone.

3. Identify the supervisory approaches which are commonly preferred by teachers' in secondary schools of Bale Zone.

4. Find out the major factors (problems) hindering the practice of school based instructional supervision in secondary schools of Bale Zone.

\section{RESEARCH DESIGN AND METHODOLOGY}

\subsection{Research Design}

The descriptive survey design was employed to study the problem. Besides, qualitative research methodology has been employed to supplement the study with the information that was collected using semi structured interview.

\subsection{Sources of Data}

The sources of data for this study were primary source which are: school teachers, instructional supervision committee members (vice-principals, senior-teachers, department-heads, and unit-leaders), school principals and secondary school supervisors of Bale zone.

\subsection{Sample and Sampling Techniques}

The study has been conducted in government secondary schools of Bale Zone. As to the data from Bale zone education office, there are 30 government secondary schools. Out of 30 government secondary schools, 9 (30\%) were selected, using simple random sampling technique. These are: Obera, Robe Galama, Goba, Dinsho, Agarfa, Mena, Ginir, Selka, Goro secondary schools.

After selecting the sample schools, school-based instructional supervisors, teachers and external supervisors were identified. Consequently, Krejcie and Morgan (1970) as cited in Cohen et al. (2005) suggested that the sample size for population size of 340 shall be 181 . As a result the researcher took $182(52.8 \%)$ sample teachers from 9 sample schools, totally having 345 teachers by using systematic random sampling technique. The total population of school principals of the sample schools ( 9 in numbers), and secondary school supervisors ( 8 in numbers) who would be found in the sample schools woreda, were included in the study.

Totally, 253 respondents means 182 teachers, 54 schools based supervision committee members (viceprincipals, senior-teachers, department- heads, and unit-leaders), 9 principals and 8 secondary school supervisors were included in the study.

\subsection{Instruments and Procedure of Data Collection}

Gathering necessary data for the study was done by using questionnaires and interviews. Both tools were developed in line with characteristics' of the respondents in the study area. After the tools were developed the validity and reliability were checked.

\subsubsection{Questionnaire}

Questionnaires were set with five sections for 182 teachers and 54 instructional supervision committee members, in light of the literature reviewed. All of the questionnaires were written in English. Both closed and open-ended types of questionnaires were constructed. The five rank responses $(5=$ strongly agree (SA), $4=$ agree (A), $3=$ undecided (UD), 2 = disagree (D), 1= strongly disagree (SD)) of Likert type questionnaires were constructed for data collection.

The pilot test was conducted to check whether the Likert scale can generate the expected information and to consider their internal consistency and to improve the items for the main research. Pilot test was conducted on 33 teachers of Robe secondary school. After the pilot test some of the items were improved and a few items were removed.

\section{Reliability of the instruments}

By using the result of the pilot test, the reliability of the items which were prepared to measure teachers' view towards the practice of instructional supervision approaches were tested. The attitude inventory items were tested 
for its reliability using Cronbach Alpha method and the result displayed ( $\mathrm{r}=0.81)$ which is reliable. According to the standard set, Cronbach Alpha value greater than 0.5 is taken as adequate for social science research purpose (Montee, 1990).

\subsubsection{Interview}

Interview was conducted with 9 principals, and 8 high school supervisors designated at the woreda level. Semistructure items were prepared for the above respondents. The process of interview was conducted in English language.

\subsection{Methods of Data Analysis}

The data collected through close ended questionnaires, were tallied and tabulated. The interpretations have been made with the help of frequency, percentage and mean. In addition, chi-square test has been applied to interpret close-ended questions, so as to test whether there is any significant difference between the response of teachers and instructional supervisors.

On the other hand, for better analysis, the 5 rank responses of the questionnaires were made to categorize into three scales (agree, undecided, disagree). Finally, the data collected through interview and open-ended questionnaires has been presented, analyzed, narrated, and organized in systematical form, by supplementing the data gathered through close ended questionnaires. In addition to this, the researcher used qualitative thematic written techniques and give attention to quotations from the respondents.

\section{PRESENTATION, ANALYSIS AND INTERPRETATION OF THE DATA}

3.1. Analysis and Interpretation of Data

3.1.1. The practice of instructional supervision approaches for teachers' professional development

3.1.1.1. The practice of supervision approach

Table1.Respondents view onself-directed and informal supervision approach

\begin{tabular}{|c|c|c|c|c|c|c|c|c|c|c|c|}
\hline \multirow[t]{3}{*}{ No } & \multirow[t]{3}{*}{ Items } & \multirow[t]{3}{*}{ Respondents } & \multicolumn{8}{|c|}{ Responses } & \multirow{3}{*}{$\begin{array}{l}\text { Computed } \\
\chi^{2}\end{array}$} \\
\hline & & & \multicolumn{2}{|c|}{ Disagree } & \multicolumn{2}{|c|}{ Undecided } & \multicolumn{2}{|c|}{ Agree } & \multicolumn{2}{|c|}{ Total } & \\
\hline & & & No & $\%$ & No & $\%$ & No & $\%$ & No & $\%$ & \\
\hline $\mathbf{a}$ & The practice of self & lirected super & sion & pproa & & & & & & & \\
\hline \multirow[t]{3}{*}{1} & \multirow{3}{*}{$\begin{array}{l}\text { Teachers assess their } \\
\text { own teaching and } \\
\text { identify need for } \\
\text { improvement. }\end{array}$} & Teacher & 61 & 33.5 & 16 & 8.8 & 105 & 57.7 & 182 & 100 & \multirow[t]{3}{*}{0.129} \\
\hline & & Supervisor & 19 & 35.2 & 4 & 7.4 & 31 & 57.4 & 54 & 100 & \\
\hline & & Total & 80 & 33.9 & 20 & 8.5 & 136 & 57.6 & 236 & 100 & \\
\hline \multirow[t]{3}{*}{2} & \multirow{3}{*}{$\begin{array}{l}\text { Teachers plan for } \\
\text { improvement after } \\
\text { assess their teaching. }\end{array}$} & Teacher & 77 & 42.3 & 5 & 2.8 & 100 & 54.9 & 182 & 100 & \multirow[t]{3}{*}{9.018} \\
\hline & & Supervisor & 20 & 37.0 & 7 & 13.0 & 27 & 50.0 & 54 & 100 & \\
\hline & & Total & 97 & 41.1 & 12 & 5.1 & 127 & 53.8 & 236 & 100 & \\
\hline \multirow[t]{3}{*}{3} & \multirow{3}{*}{$\begin{array}{l}\text { Teachers do have } \\
\text { freedom to set the } \\
\text { plan in the way they } \\
\text { like }\end{array}$} & Teacher & 103 & 56.6 & 14 & 7.7 & 65 & 35.7 & 182 & 100 & \multirow[t]{3}{*}{1.018} \\
\hline & & Supervisor & 27 & 50.0 & 6 & 11.1 & 21 & 38.9 & 54 & 100 & \\
\hline & & Total & 130 & 55.1 & 20 & 8.5 & 86 & 36.4 & 236 & 100 & \\
\hline & \multicolumn{11}{|c|}{ The practice of informal supervision approach } \\
\hline \multirow[t]{3}{*}{4} & \multirow{3}{*}{$\begin{array}{l}\text { Supervisor suddenly } \\
\text { supervise teacher } \\
\text { without plan with } \\
\text { them }\end{array}$} & Teacher & 57 & 31.3 & 26 & 14.3 & 99 & 54.4 & 182 & 100 & \multirow[t]{3}{*}{4.666} \\
\hline & & Supervisor & 25 & 46.3 & 8 & 14.8 & 21 & 38.9 & 54 & 100 & \\
\hline & & Total & 82 & 34.7 & 34 & 14.4 & 120 & 50.8 & 236 & 100 & \\
\hline \multirow[t]{3}{*}{5} & \multirow{3}{*}{$\begin{array}{l}\text { Supervisors } r \text { have } \\
\text { brief but frequent } \\
\text { plan to supervise } \\
\text { teacher. }\end{array}$} & Teacher & 91 & 50.0 & 25 & 13.7 & 66 & 36.3 & 182 & 100 & \multirow[t]{3}{*}{0.125} \\
\hline & & Supervisor & 26 & 48.1 & 7 & 13.0 & 21 & 38.9 & 54 & 100 & \\
\hline & & Total & 117 & 49.6 & 32 & 13.5 & 87 & 36.9 & 236 & 100 & \\
\hline \multirow[t]{3}{*}{6} & \multirow{3}{*}{$\begin{array}{l}\text { Supervisor work as } \\
\text { instructional partner } \\
\text { of teachers. }\end{array}$} & Teacher & 93 & 51.1 & 17 & 9.3 & 72 & 39.6 & 182 & 100 & \multirow[t]{3}{*}{4.849} \\
\hline & & Supervisor & 24 & 44.4 & 11 & 20.4 & 19 & 35.2 & 54 & 100 & \\
\hline & & Total & 117 & 49.6 & 28 & 11.9 & 91 & 38.5 & 236 & 100 & \\
\hline
\end{tabular}

The table value $\chi^{2}=5.991$ at 0.05 significant levels with two degrees of freedom

Regarding the activities of Teachers to assess their own teaching and identify need for improvement 105 $(57.7 \%)$ teacher and $31(57.4 \%)$ instructional supervisor respondents witnessed that the existence of the practice.

A chi-square test was also calculated to check whether the opinion difference exists among the two groups or not. As a result, the table value of $\chi^{2}=5.991$ was found to be extremely greater than the calculated $\chi^{2}=0.129$, for $\mathrm{df}=2$, at 0.05 level of significance, which implies there is no significant difference among the respondents response regarding the practice. Furthermore, from the interview with the school principals and secondary school 
supervisors; teachers were assessing their own teaching and identify need for improvement.

Therefore, as indicated in the chi-square results and from the data gained from the interview, it is possible to conclude that the role of teachers in assessing their own teaching and identify need for improvement is almost implemented sufficiently.

With regard to item 2, whether teachers plan for improvement after assess their teaching or not, $100(54.9 \%)$ teacher respondents and $27(50.0 \%)$ of supervisor respondents responded that teachers plan for improvement after assess their teaching.

The computed chi-square value $\chi^{2}=9.018$ for item 2 exceeds the table value $\chi^{2}=5.991$ at 0.05 significant levels with two degree of freedom. This means, there is a significant difference in response of the two groups of respondents about their knowledge on the efforts of teachers' to plan for improvement after assess their teaching.

In addition to this, the interview with school principals and secondary school supervisors assured that teachers were capable enough to shoulder responsibilities of plan for improvement after assess their teaching. Therefore, based on the result of the chi-square tests and data obtained from interview, it is possible to conclude that teachers do play their role to plan for improvement.

In item 3, respondents requested whether teachers do have freedom to set the plan in the way they like or not. In respect to this totally $130(55.1 \%)$ respondents asserted their disagreement. The computed chi-square $\chi^{2}$ $=1.018$ was less than the table value $\chi^{2}=5.991$ at a significance level of 0.05 and two degrees of freedom indicated no significant difference between the views of two groups.

As indicated in table 1, item 4, respondents asked whether or not supervisors suddenly supervise teacher without plan with them. In this respect, 99 (54.4\%) teachers agreed on the practice. Whereas $25(46.3 \%)$ of supervisor respondents confirmed their disagreement. The chi-square test was also calculated to check whether the opinion difference exists among two groups or not. As a result, the computed value $\chi^{2}=4.666$ is less than the table value of $\chi^{2}=5.991$, for $\mathrm{df}=2$, at 0.05 level of significance, which implies there is statistically no significant difference between the respondents responses. Instructional supervisors claimed that they have plan with teachers before inter the class. But in the interview with the school principals and secondary school supervisors, most of the interviewees claimed that instructional supervisors inter the class without plan with teachers.

Regarding whether supervisors have brief but frequent plan to supervise teachers or not, $91(50.0 \%)$ teachers and $26(48.1 \%)$ supervisors totally $117(49.6 \%)$ respondents were showed their disagreement. This implied that the practice were ineffective. The computed chi-square value $\chi^{2}=0.125$ is extremely lower than the table value $\chi^{2}=5.991$ at a significant level of .05 with two degrees of freedom. This implies that there is no significant difference between the two groups of respondents concerning the supervisors' plan to supervise teacher.

Item 6 of table 1 indicated 93(51.1\%) teachers and 24(44.4\%) supervisors totally $117(49.6 \%)$ of respondents indicated that the activity was not accomplished by supervisors. The computed chi-square value $\chi^{2}=$ 4.849 is lower than the table value $\chi^{2}=5.991$ at a significant level of .05 with two degrees of freedom. This implies that there is no significance difference between the two groups of respondents concerning the supervisors' role to work as instructional partner of teachers.

On the other hand, from the interview held with the principals and secondary school supervisors, instructional supervisors were not have plan with teachers and work as instructional partner of teachers. Hence, it is possible to conclude that the role of supervisors work as instructional partner of teachers and frequent plan with them to enhance professional competence of teachers is not almost implemented sufficiently.

From the above table the researcher concluded that teachers did not freedom to plan in the way they like and hold responsibility for their plan. In supporting the above idea Atiklt (2008) stated schools are forced teachers to plan according to the guide line of the school. On the other hand the finding indicated in table 1 , the researcher concluded that, the practice of informal supervision approach to promote teachers professional development in Bale zone was unsatisfactory. 
3.1.1.2. The practice of supervision approach

Table2. Respondents view on the practice of inquire-based and clinical supervision approach

\begin{tabular}{|c|c|c|c|c|c|c|c|c|c|c|c|}
\hline \multirow[t]{3}{*}{ No } & \multirow[t]{3}{*}{ Items } & \multirow[t]{3}{*}{ Respondents } & \multicolumn{8}{|c|}{ Responses } & \multirow{3}{*}{$\begin{array}{l}\text { Computed } \\
\chi^{2}\end{array}$} \\
\hline & & & \multicolumn{2}{|c|}{ Disagree } & \multicolumn{2}{|c|}{ Undecided } & \multicolumn{2}{|c|}{ Agree } & \multicolumn{2}{|c|}{ Total } & \\
\hline & & & No & $\%$ & No & $\%$ & No & $\%$ & No & $\%$ & \\
\hline \multicolumn{12}{|c|}{ The practice of inquire-based supervision approach } \\
\hline \multirow[t]{3}{*}{1} & \multirow{3}{*}{$\begin{array}{l}\text { Teachers do action } \\
\text { research to solve their } \\
\text { teaching. }\end{array}$} & Teacher & 77 & 42.3 & 21 & 11.5 & 84 & 46.2 & 182 & 100 & \multirow[t]{3}{*}{1.475} \\
\hline & & Supervisor & 26 & 48.1 & 8 & 14.8 & 20 & 37.1 & 54 & 100 & \\
\hline & & Total & 103 & 43.6 & 29 & 12.3 & 104 & 44.1 & 236 & 100 & \\
\hline \multirow[t]{3}{*}{2} & \multirow{3}{*}{$\begin{array}{lr}\text { Teachers } & \text { identify } \\
\text { problems } & \text { and } \\
\text { developing } & \text { strategy } \\
\text { for its solution. } & \end{array}$} & Teacher & 107 & 58.8 & 23 & 12.6 & 52 & 28.6 & 182 & 100 & \multirow[t]{3}{*}{2.184} \\
\hline & & Supervisor & 28 & 51.9 & 5 & 9.3 & 21 & 38.9 & 54 & 100 & \\
\hline & & Total & 135 & 57.2 & 28 & 11.9 & 73 & 30.9 & 236 & 100 & \\
\hline \multirow[t]{3}{*}{3} & \multirow{3}{*}{$\begin{array}{l}\text { Teachers work } \\
\text { collaboratively } \\
\text { solve their problem. }\end{array}$} & Teacher & 107 & 58.8 & 16 & 8.8 & 59 & 32.4 & 182 & 100 & \multirow[t]{3}{*}{0.590} \\
\hline & & Supervisor & 33 & 61.1 & 3 & 5.6 & 18 & 33.3 & 54 & 100 & \\
\hline & & Total & 140 & 59.3 & 19 & 8.1 & 77 & 32.6 & 236 & 100 & \\
\hline \multicolumn{12}{|c|}{ The practice of clinical supervision approach } \\
\hline \multirow[t]{3}{*}{4} & \multirow{3}{*}{$\begin{array}{l}\text { Supervisor and } \\
\text { teacher make mutual } \\
\text { agreement on the } \\
\text { period and the lesson } \\
\text { to be observed. }\end{array}$} & Teacher & 109 & 59.9 & 17 & 9.3 & 56 & 30.7 & 182 & 100 & \multirow[t]{3}{*}{0.184} \\
\hline & & Supervisor & 31 & 57.4 & 6 & 11.1 & 17 & 31.5 & 54 & 100 & \\
\hline & & Total & 140 & 59.3 & 23 & 9.8 & 73 & 30.9 & 236 & 100 & \\
\hline \multirow[t]{3}{*}{5} & \multirow{3}{*}{$\begin{array}{l}\text { Supervisors and } \\
\text { teachers discuss on } \\
\text { the content, objective } \\
\text { and methods of } \\
\text { teaching before } \\
\text { observation. }\end{array}$} & Teacher & 98 & 53.9 & 21 & 11.5 & 63 & 34.6 & 182 & 100 & \multirow[t]{3}{*}{2.914} \\
\hline & & Supervisor & 32 & 59.3 & 2 & 3.7 & 20 & 37.0 & 54 & 100 & \\
\hline & & Total & 130 & 55.1 & 23 & 9.7 & 83 & 35.2 & 236 & 100 & \\
\hline \multirow[t]{5}{*}{6} & Supervisors use & Teacher & 112 & 61.5 & 9 & 4.9 & 61 & 33.5 & 182 & 100 & 9.959 \\
\hline & observation & Supervisor & 24 & 44.4 & 9 & 16.7 & 21 & 38.9 & 54 & 100 & \\
\hline & instrument to collect & Total & 136 & 57.6 & 18 & 7.6 & 82 & 34.8 & 236 & 100 & \\
\hline & data on the lesson & Supervisor & 14 & 25.9 & 6 & 11.1 & 34 & 63.0 & 54 & 100 & \\
\hline & being thought & Total & 82 & 34.7 & 19 & 10.4 & 135 & 57.2 & 236 & 100 & \\
\hline 7 & Supervisors focus too & Teacher & 110 & 60.4 & 14 & 7.7 & 58 & 31.9 & 182 & 100 & 1.470 \\
\hline & much on weakness & Supervisor & 30 & 55.5 & 7 & 13.0 & 17 & 31.5 & 54 & 100 & \\
\hline & and little on strength & Total & 140 & 59.3 & 21 & 8.9 & 75 & 31.8 & 236 & 100 & \\
\hline & of teacher. & Supervisor & 32 & 59.3 & 4 & 7.4 & 18 & 33.3 & 54 & 100 & \\
\hline & & Total & 125 & 53.0 & 30 & 12.7 & 81 & 34.3 & 236 & 100 & \\
\hline 8 & Supervisors give & Teacher & 123 & 67.6 & 14 & 7.7 & 45 & 24.7 & 182 & 100 & 0.205 \\
\hline & constructive feedback & Supervisor & 35 & 64.8 & 4 & 7.4 & 15 & 27.8 & 54 & 100 & \\
\hline & $\begin{array}{l}\text { for teacher after } \\
\text { observation. }\end{array}$ & Total & 158 & 66.9 & 18 & 7.6 & 60 & 25.4 & 236 & 100 & \\
\hline
\end{tabular}

The table value $\chi^{2}=5.991$ at 0.05 significant levels with two degrees of freedom

In table 6 item 1, respondents were asked whether or not teachers do action research to solve their teaching. Accordingly, $84(46.2 \%)$ teachers agreed on the practice. On the other hand, $26(48.1 \%)$ supervisor respondents disagreed that teachers do not solve their teaching through action research. But as the interview with principals and secondary school supervisors indicates that, teachers do action research for the fulfillment of their performance appraisal in steady of teaching improvement.

A chi-square test was also computed to see whether there was difference among the responses of the two groups. Hence, the table value $\chi^{2}=5.991$ was greater than the computed chi-square values for item 1 at significance level of 0.05 with two degree of freedom, which implies there is no significant difference among the two group of respondents.

As one secondary school supervisors said and most of the interview participants accepted, the concept of action research is not in line with the science of action research in our school. Most teachers fill unhappy when they asked to do action research on their teaching. Most of the time, they see as additional duty given by the leaders and most of the action research done in our school were valueless. They did simply for answering question raised during their performance appraisal. 
(Girma February 15:2013)

As shown under table 2 item 2 and 3, the majority of teachers and supervisor respondents, that is 135 $(57.2 \%)$ and $140(59.3 \%)$ for item 2 and 3 respectively rated their disagreement that teachers do not identify problems and developing strategy for its solution and work collaboratively to solve their problem.

A chi-square test was also computed to see whether there was difference among the responses of the two groups of respondents. Hence, the table value of $\chi^{2}=5.991$ was greater than the computed chi-square values $\chi^{2}=2.184$ and $x^{2}=0.590$ respectively for item 2 and 3 at significant level of 0.05 with two degrees of freedom, which implies no significant difference among the two group of respondents.

Similarly, most of the informants who participated in the interview express teachers do not work collaboratively by identifying their problem for improvement. Therefore, based on the response of majority and computed chi-squarevalue, it is possible to concluded that inquire-based supervision approach have not practiced sufficiently for the development of teachers in the sample schools of Bale Zone.

As shown in Table 2 of item 4, teachers and supervisors respondents were asked whether or not supervisors and teachers make mutual agreement on the period and the lesson to be observed. Consequently, totally 140 $(59.3 \%)$ respondents assured that there is no mutual agreement on the period and lesson to be observed. The computed chi-square value $x^{2}=0.184$ is lower than the table value $\left(x^{2}=5.991\right)$ at a significant level of 0.05 with two degree of freedom. This implies that there is no significant difference among the response of the two groups of respondents.

Responses for item 5, in the same table totally 130 (55.1\%) respondents had replied that supervisors made no arrangements with teachers on the objective of classroom observation. Accordingly the calculated chi-square value $\left(\chi^{2}=2.914\right)$ is below the table value $\left(\chi^{2}=5.991\right)$ at significant level of 0.05 with two degree of freedom. Hence, it can be concluded that there is no significant statistical difference between the two groups of respondents' response.

Similarly, during the interview conducted with them, the school principals and secondary school supervisors responded that, instructional supervisors did not reach an agreement on the period and the lesson to be observed before actual classroom observation and objective of the observation. Besides, the interviewees responded that supervisors fail to examine the lesson prepared by the teachers before actual classroom presentation.

Therefore, from the results of the chi-square tests and the data obtained from the interview, one can conclude that pre classroom observation in schools under study have taken place without ensuring mutual understanding and agreement, which affect the process of classroom observation.

Related to pre class-observation, Lucio and McNeil (1979:264) stated that pre observation conference is the improvement cycle where the teacher presents to the supervisors the instructional objectives, methods and techniques of evolution he or she intended to use in lesson to be observed. Hence, the main objective of pre class observation conference should be focus on establishing teachers' acceptance and agreement. To this end, teachers together with supervisors must have an opportunity in discussing and deciding on the purpose, criteria, frequency, procedures instruments and follow up activities prior to the actual classroom observation. But these accounts seem to be less considered by the school supervisors as they were confirmed by the data analysis in above table.

As can be observed in table 2 item 6 teacher and supervisor respondents were asked whether or not supervisors use observation instrument to collect data on the lesson being thought. To this end, $112(61.5 \%)$ teacher and $24(44.4 \%)$ supervisor respondents confirmed the non-existence of such practice. In this regard, the computed chi-square value $\chi^{2}=9.959$ is greater than the table value $\chi^{2}=5.991$ at significant level 0.05 with two degree of freedom. Thus, this shows that there is significance different between the two groups of respondents' opinion.

As shown under item 7 of table 2, $110(60.4 \%)$ teacher and 30 (55.5\%) supervisor respondents disagreed that supervisors focus too much on weakness and little on the strength of teachers during post observation discussion. On contrary, $58(31.9 \%)$ of teachers and $17(31.5 \%)$ of supervisors asserted that the school supervisors were focusing too much on weakness during post observation discussion.

As it can be observed form the table 2 above, the computed chi-square value $\chi^{2}=3.030, \chi^{2}=1.470, \chi^{2}=2.093$ and $\chi^{2}=0.205$ of items 7 to 8 respectively are less than the table value $x^{2}=5.991$ at 0.5 significant level with two degrees of freedom. This showed that there is no significant difference among the response of the two groups of respondents concerning the application of the post classroom observation conference activities like concentrating on whether teachers stand in performance, meeting focus on both the weakness and strength of classroom teaching and providing constructive feedback.

Furthermore, the information obtained from school principals and secondary school supervisors revealed that the post-classroom observation conferences were carried on the department level, not on an individual teacher basis. Most of the respondents of interview argued that instructional supervisors might not get situations 
comfort to conduct post class conference with individual teacher. This is due to time constraints and large number of teachers in the schools.

Thus, based on the results of chi-square and the data gained from interview, it is safe to conclude that the post observation conference was no held properly. This is mainly because, it is failed to address the interest of individual teachers in practicing the different strategies of instructional supervision.

In light to the above analysis, Harris (1991:100) as cited in Chanyalew (2005) revealed that the major purpose of post observation conference is to get feedback to the teacher about her/his performance. Following up activity involves some kind of re-recording of data analysis, a plan for feedback other teacher and other appropriate activities growing out of observation. Generally the practice of clinical supervision approach in secondary school of Bale zone was not satisfactory.

Totally, it is safe that to conclude from the above two tables the practice of supervision approaches is failed to address teachers' professional development in sample secondary schools of Bale zone. In line to this Haile (2006) stated that the practice of supervision approaches are not as indicated in supervision manual.

3.1.2. Supervision approach preferred by teachers

Table3. Respondents view on supervision approach they prefer

\begin{tabular}{|c|c|c|c|c|c|c|c|c|c|c|c|c|}
\hline \multirow[t]{3}{*}{ Items } & \multirow[t]{3}{*}{ Respondents } & \multicolumn{10}{|c|}{ Responses } & \multirow{3}{*}{$\begin{array}{l}\text { Computed } \\
\chi^{2}\end{array}$} \\
\hline & & \multicolumn{2}{|c|}{ Clinical } & \multicolumn{2}{|c|}{ informal } & \multicolumn{2}{|c|}{$\begin{array}{c}\text { Self- } \\
\text { directed }\end{array}$} & \multicolumn{2}{|c|}{$\begin{array}{c}\text { Inquire- } \\
\text { based }\end{array}$} & \multicolumn{2}{|c|}{ Total } & \\
\hline & & No & $\%$ & No & $\%$ & No & $\%$ & No & $\%$ & Nog & $\%$ & \\
\hline \multirow{3}{*}{$\begin{array}{l}\text { Which } \\
\text { supervision } \\
\text { approach do you } \\
\text { prefer? }\end{array}$} & Teacher & $\overline{91}$ & 50.0 & 9 & 5.0 & $3 \overline{7}$ & 20.3 & $4 \overline{5}$ & 24.7 & 182 & 100 & \multirow[t]{3}{*}{12.814} \\
\hline & Supervisor & 24 & 44.4 & 10 & 18.5 & 5 & 9.3 & 15 & 27.8 & 54 & 100 & \\
\hline & Total & 115 & 48.7 & 19 & 8.1 & 42 & 17.8 & 60 & 25.4 & 236 & 100 & \\
\hline
\end{tabular}

The table value $\chi^{2}=7.815$ at 0.05 significant levels with three degrees of freedom

As indicated in table 3, most of the respondents, $91(50.0 \%)$ teacher and 24 (44.4\%) of supervisor respondents confirmed that they preferred clinical supervision approach. The chi-square test was also calculated to check whether the opinion difference exists among the two groups or not. As a result, the computed value $\chi^{2}=$ 12.814 is greater than the table value of $\chi^{2}=7.815$, for $\mathrm{df}=3$, at 0.05 level of significance, which implies there is statistically significant difference between the respondents responses. In the interview with the school principals and secondary school supervisors, most of the interviewees claimed clinical supervision approach was the best approach for teachers' professional development. Because both teachers and supervisors agree on the contents, method and lesson observed before observation, discuss on the strength and weakness, and the way of improving the weakness. Therefore, it is possible to conclude that clinical supervision approach is the better way for professional development of teachers.

\subsubsection{The practices of instructional supervisors in promoting teachers professional development}

Supervisors have to work effectively for effective implementation of instructional supervision. As it has been indicated in the literature, supervision has the duties to help teachers to organize and provide professional training programs and gives induction to new teachers as a means to achieve professional development of teachers. In respect to this, respondents were requested to suggest whether supervisors perform those tasks during provision of support to teachers. The results obtained are presented in the following table. 
Table4. The efforts of instructional supervisors in promoting teachers professional development

\begin{tabular}{|c|c|c|c|c|c|c|c|c|c|c|c|}
\hline \multirow[t]{3}{*}{ No } & \multirow[t]{3}{*}{ Items } & \multirow[t]{3}{*}{ Respondents } & \multicolumn{8}{|c|}{ Responses } & \multirow{3}{*}{$\begin{array}{l}\text { Computed } \\
\chi^{2}\end{array}$} \\
\hline & & & \multicolumn{2}{|c|}{ Disagree } & \multicolumn{2}{|c|}{ Undecided } & \multicolumn{2}{|c|}{ Agree } & \multicolumn{2}{|c|}{ Total } & \\
\hline & & & No & $\%$ & No & $\%$ & No & $\%$ & No & $\%$ & \\
\hline \multirow[t]{3}{*}{1} & \multirow{3}{*}{$\begin{array}{l}\text { Supervisors organize } \\
\text { and support induction } \\
\text { programs for beginner } \\
\text { or new teachers in the } \\
\text { school. }\end{array}$} & Teacher & $6 \overline{6}$ & 36.3 & 21 & 11.5 & $9 \overline{5}$ & 52.2 & 182 & 100 & \multirow[t]{3}{*}{0.896} \\
\hline & & Supervision & 19 & 35.2 & 4 & 7.4 & 31 & 57.4 & 54 & 100 & \\
\hline & & Total & 85 & 36.0 & 25 & 10.6 & 126 & 53.4 & 236 & 100 & \\
\hline \multirow[t]{3}{*}{2} & \multirow{3}{*}{$\begin{array}{lr}\text { Supervisors } & \text { facilitate } \\
\text { professional } & \\
\text { development } & \text { of } \\
\text { teachers } & \text { through } \\
\text { mentoring programs. }\end{array}$} & Teacher & 93 & 51.1 & 11 & 6.0 & 78 & 42.9 & 182 & 100 & \multirow[t]{3}{*}{1.029} \\
\hline & & Supervision & 29 & 53.7 & 5 & 9.3 & 20 & 37.0 & 54 & 100 & \\
\hline & & Total & 122 & 51.7 & 16 & 6.8 & 98 & 41.5 & 236 & 100 & \\
\hline \multirow[t]{3}{*}{3} & \multirow{3}{*}{$\begin{array}{l}\text { Supervisors contribute } \\
\text { to enhance } \\
\text { professional } \\
\text { competence of } \\
\text { teachers by providing } \\
\text { latest information on } \\
\text { teaching strategies }\end{array}$} & Teacher & 123 & 67.6 & 12 & 6.6 & 47 & 25.8 & 182 & 100 & \multirow[t]{3}{*}{3.753} \\
\hline & & Supervision & 29 & 53.7 & 4 & 7.4 & 21 & 38.9 & 54 & 100 & \\
\hline & & Total & 152 & 64.4 & 16 & 6.8 & 68 & 28.8 & 236 & 100 & \\
\hline \multirow[t]{5}{*}{4} & \multirow{5}{*}{$\begin{array}{l}\text { Supervisors organize } \\
\text { collegial or pear } \\
\text { coaching techniques } \\
\text { of supervision for } \\
\text { teachers professional } \\
\text { growth }\end{array}$} & Teacher & 107 & 58.8 & 14 & 7.7 & 61 & 33.5 & 182 & 100 & \multirow[t]{5}{*}{0.769} \\
\hline & & Supervision & 32 & 59.3 & 6 & 11.1 & 16 & 29.6 & 54 & 100 & \\
\hline & & Total & 139 & 58.9 & 20 & 8.5 & 77 & 32.6 & 236 & 100 & \\
\hline & & Supervision & 26 & 48.1 & 12 & 22.2 & 16 & 29.6 & 54 & 100 & \\
\hline & & Total & 107 & 45.3 & 43 & 18.2 & 86 & 36.5 & 236 & 100 & \\
\hline \multirow[t]{3}{*}{5} & \multirow{3}{*}{$\begin{array}{l}\text { Supervisors assist } \\
\text { teachers to undertake } \\
\text { joint planning of } \\
\text { experience sharing } \\
\text { programs in school } \\
\text { context }\end{array}$} & Teacher & 84 & 46.2 & 28 & 15.4 & 70 & 38.5 & 182 & 100 & \multirow[t]{3}{*}{1.430} \\
\hline & & Supervision & 28 & 51.9 & 10 & 18.5 & 16 & 29.6 & 54 & 100 & \\
\hline & & Total & 112 & 47.5 & 38 & 16.1 & 86 & 36.4 & 236 & 100 & \\
\hline \multirow[t]{5}{*}{6} & \multirow{5}{*}{$\begin{array}{l}\text { Training programs at } \\
\text { school level focuses in } \\
\text { achieving continuous } \\
\text { professional growth of } \\
\text { teachers. }\end{array}$} & Teacher & 95 & 52.2 & 18 & 9.9 & 69 & 37.9 & 182 & 100 & \multirow[t]{5}{*}{5.120} \\
\hline & & Supervision & 31 & 57.4 & 10 & 18.5 & 13 & 24.1 & 54 & 100 & \\
\hline & & Total & 126 & 53.4 & 28 & 11.9 & 82 & 34.7 & 236 & 100 & \\
\hline & & Supervision & 32 & 59.3 & 6 & 11.1 & 16 & 29.6 & 54 & 100 & \\
\hline & & Total & 146 & 61.9 & 20 & 8.5 & 70 & 29.7 & 236 & 100 & \\
\hline
\end{tabular}

The table value $\chi^{2}=5.991$ at 0.05 significant levels with two degrees of freedom

As indicated in table 4, item 1, respondents asked whether or not supervisors organize and support induction programs for newly employed teachers. In this respect, 95 (52.2\%) teacher and $31(57.4 \%)$ of supervisor respondents confirmed that induction program have been taken place in their school. The chi-square test was also calculated to check whether the opinion difference exists among two groups or not. As a result, the computed chi-square value $\mathrm{x}^{2}=0.896$ was less than the table value of $\chi^{2}=5.991$, for $\mathrm{df}=2$, at 0.05 level of significance, which implies there is no statistically significant difference between the respondents responses. In the interview with the school principals and secondary school supervisors, all the interviewees claimed that teachers had chance of getting induction or mentoring service while they were beginner or new to the schools they were assign to teach. This might depict us that due to the new CPD program started in the year 2007, the beginner teacher had a chance of having an induction or mentoring program in schools of the region. Therefore, it is possible to conclude that recently there is an attempt serve new and beginner teachers to develop their selfconfidence so as to fulfill their duties and responsibilities. In support of this, McBirdge (1996:15) argued that Mentoring or induction is aimed at helping new requited teachers to develop self-confidence and to avoiding unnecessary tension and future malfunction.

Regarding the practice of facilitating professional development of teachers through monitoring programs, respondents were requested whether supervisors endeavor to achieve this task or not. Thus, $93(51.1 \%)$ teachers and $29(53.7 \%)$ supervisors totally $122(51.7 \%)$ respondents showed their disagreement. This implied that the practice were ineffective.

Item 3 of Table 4 indicated totally $152(64.4 \%)$ of respondents indicated that the activity was not 
accomplished by supervisors. The computed chi-square value $\chi^{2}=3.753$ is lower than the table value $\chi^{2}=5.991$ at a significant level of .05 with two degrees of freedom. This implies that there is no significant difference between the two groups of respondents concerning the supervisors' role to enhance professional competence of teachers.

On the other hand, from the interview held with the principals, vice principals and secondary school supervisors, instructional supervisors were not using different mechanisms to enhance professional competence of teachers by providing the latest information. Hence, it is possible to conclude that the role of supervisors to enhance professional competence of teachers is not almost implemented sufficiently.

In light of this idea, Hewto (1988 cited in Moon et al., 2006:151) asserted that school based professional development as planned process which enhances the quality of pupil learning by identifying, clarifying and meeting the individual needs of staff with in a context of the institution as a whole. It can be achieved through variety of means such as conferences, workshops, seminars, meetings, study groups, research and projects, visitation to other schools and classrooms. When a teaching staff competent through the practices the overall objective will be achieved.

Respondents were asked whether supervisors organizing collegial or peer coaching techniques of supervision for teachers' professional development. In respect to this, 107 (58.8\%) teachers and $32(59.3 \%)$ supervisors totally $139(58.9 \%)$ respondents asserted their disagreement

As shown in the same table, item 6, teacher and supervisor respondents asked whether or not trainings at school level focuses in achieving continuous professional growth of teachers. In this respect, totally 126 (53.4\%) respondents showed their disagreement. Hence, according to both respondents, this supervisory practice was unsatisfactory.

Thus, as most of the interview participants agreed, a few number of training might not allowed them to judge enough whether school level trainings organized by instructional supervisors enable teacher to bring the expected outcome in professional competence of teachers. Regarding the reasons why school supervisors neglected organizing trainings, most of the interview participants agreed upon: supervisors' incompetence in organizing trainings following the appropriate procedures; lack of commitment and interests of supervisors in carrying out their duties and responsibilities, and supervisors' engagement in routine tasks.

From the finding above, it could be concluded that school level in-service training organized by instructional supervisors to enhance teachers' competence were found unsatisfactory, however, promoting these tasks were possibly the dominant responsibilities that instructional supervisors should carryout being assigned as supervisor.

Supporting this, as noted in the literature, Lue (2004) argued that in service training at school level is one of the means to achieve professional development of teachers' of the school. Through the training, teachers could improve teaching methodologies and curriculum innovations, develop mutual support and stand for common goals. Similarly, Moon et al. (2006) described, school based staff development as a planned process of development which enhances the quality of pupil learning by identifying, clarifying and meeting the individual needs of staff with in a context of the instruction as a whole. But this is not practiced in secondary school of Bale zone

\subsubsection{Contribution of instructional supervision approaches for teachers' professional development}

Schools are the mission centers where the actual teaching learning takes place. Hence, making supervision a continuous responsibility at this level is crucial. One has to know how supervision at school level best be implemented, its purpose and effect on teaching learning process. Whatever attempt made at any level outside school regarding supervision the attempt will be meaningless unless supervisory activities are strengthening at school level (OREB, 2007 and MoE, 1995). 
Table5. Respondents views on contribution of instructional supervision approaches

\begin{tabular}{|c|c|c|c|c|c|c|c|c|c|c|c|}
\hline \multirow[t]{3}{*}{ No } & \multirow[t]{3}{*}{ Items } & \multirow[t]{3}{*}{ Respondents } & \multicolumn{8}{|c|}{ Responses } & \multirow{3}{*}{$\begin{array}{l}\text { Computed } \\
\chi^{2}\end{array}$} \\
\hline & & & \multicolumn{2}{|c|}{ Disagree } & \multicolumn{2}{|c|}{ Undecided } & \multicolumn{2}{|c|}{ Agree } & \multicolumn{2}{|c|}{ Total } & \\
\hline & & & No & $\%$ & No & $\%$ & No & $\%$ & No & $\%$ & \\
\hline \multirow[t]{5}{*}{1} & \multirow{5}{*}{$\begin{array}{l}\text { Instructional } \\
\text { supervision helps } \\
\text { teachers to arrange } \\
\text { conducive situation to } \\
\text { instructional } \\
\text { improvement }\end{array}$} & Teacher & 107 & 58.8 & 7 & 3.8 & 68 & 37.4 & 182 & 100 & \multirow[t]{5}{*}{10.941} \\
\hline & & Supervision & 18 & 33.3 & 4 & 7.4 & 32 & 59.3 & 54 & 100 & \\
\hline & & Total & 125 & 53.0 & 11 & 4.7 & 100 & 42.4 & 236 & 100 & \\
\hline & & Supervision & 21 & 38.9 & 4 & 7.4 & 29 & 53.7 & 54 & 100 & \\
\hline & & Total & 126 & 53.4 & 16 & 6.8 & 94 & 40.3 & 236 & 100 & \\
\hline \multirow[t]{5}{*}{2} & \multirow{5}{*}{$\begin{array}{l}\text { Instructional } \\
\text { supervision practice } \\
\text { helps teachers to create } \\
\text { cooperative spirit with } \\
\text { in school community }\end{array}$} & Teacher & 103 & 56.6 & 12 & 6.6 & 67 & 36.8 & 182 & 100 & \multirow[t]{5}{*}{0.910} \\
\hline & & Supervision & 27 & 50 & 5 & 9.3 & 22 & 40.7 & 54 & 100 & \\
\hline & & Total & 130 & 55.1 & 17 & 7.2 & 89 & 37.7 & 236 & 100 & \\
\hline & & Supervision & 35 & 64.8 & 4 & 7.4 & 15 & 27.8 & 54 & 100 & \\
\hline & & Total & 145 & 61.4 & 13 & 5.5 & 78 & 33.1 & 236 & 100 & \\
\hline \multirow[t]{3}{*}{3} & \multirow{3}{*}{$\begin{array}{l}\text { Instructional } \\
\text { supervision organizes } \\
\text { teachers to supervise } \\
\text { each other on team } \\
\text { basis. }\end{array}$} & Teacher & 96 & 52.7 & 26 & 14.3 & 60 & 33.0 & 182 & 100 & \multirow[t]{3}{*}{0.992} \\
\hline & & Supervision & 32 & 59.3 & 8 & 14.8 & 14 & 25.9 & 54 & 100 & \\
\hline & & Total & 128 & 54.2 & 34 & 14.4 & 74 & 31.4 & 236 & 100 & \\
\hline \multirow[t]{3}{*}{4} & \multirow{3}{*}{$\begin{array}{l}\text { Instructional } \\
\text { supervision assists } \\
\text { teachers in } \\
\text { implementation of new } \\
\text { curriculum. }\end{array}$} & Teacher & 93 & 51.1 & 25 & 13.8 & 64 & 35.1 & 182 & 100 & \multirow[t]{3}{*}{0.045} \\
\hline & & Supervision & 27 & 50.0 & 8 & 14.8 & 19 & 35.2 & 54 & 100 & \\
\hline & & Total & 120 & 50.8 & 33 & 14.0 & 83 & 35.2 & 236 & 100 & \\
\hline \multirow[t]{3}{*}{5} & \multirow{3}{*}{$\begin{array}{lr}\text { Instructional } & \\
\text { supervisors } & \text { facilitate } \\
\text { teachers' } & \text { parent } \\
\text { partnership. } & \end{array}$} & Teacher & 88 & 48.4 & 25 & 13.7 & 69 & 37.9 & 182 & 100 & \multirow[t]{3}{*}{4.603} \\
\hline & & Supervision & 32 & 59.3 & 10 & 18.5 & 12 & 22.2 & 54 & 100 & \\
\hline & & Total & 120 & 50.9 & 35 & 14.8 & 81 & 34.3 & 236 & 100 & \\
\hline
\end{tabular}

The table value $\chi^{2}=5.991$ at 0.05 significant levels with two degrees of freedom

Regarding the effort of supervision to arrange and promoting situation conducive to instructional improvement 107 (58.8\%) teacher respondents witnessed that they never hold the practice. Whereas, 32 (59.3\%) of supervisor respondents pointed out that the non-existence of the practice.

A chi-square test was also calculated to check whether the opinion difference exists among the two groups or not. As a result, the table value of $\chi^{2}=5.991$ was found to be less than the calculated $\chi^{2}=10.941$, for $\mathrm{df}=2$, at 0.05 level of significant, which implies there is statistically significant difference among the respondents response regarding item 1 of table 5 .

Furthermore, from the interview with the school principals and secondary school supervisors; it was found that instructional supervisors were not arranging and promoting situation conducive to instructional improvement. The reason they mentioned for this was lack of time, lack of knowledge and skills of how, to arrange conducive working atmosphere to instructional improvement.

Therefore, as indicated in the chi-square results and from the data gained in the interview, it is possible to conclude that the role of supervisors in arranging and promoting working atmosphere to instructional improvement is not almost implemented sufficiently.

Respondents requested whether instructional supervision help teachers to create cooperative spirit within school community or not. In respect to this 103 (56.6\%) teachers and $27(50.0 \%)$ supervisors totally $130(55.1 \%)$ respondents asserted their disagreement. The computed chi-square indicated no significant difference between the views of two groups.

In line with this, OREB (2007:14) in its guideline for educational supervision works for schools pointed out teachers have to be encouraged by supervisors of their own school to share their experiences of good methodology, classroom organization, lesson plan and media preparation and personal life.

Item 3 of Table 5 indicate, teacher and supervisor respondents asked about their view on whether or not instruction supervision encouraged strong group moral and unifying teachers into effective team. In this case, $128(54.2 \%)$ respondents depicted their disagreements which indicate tasks were performed effectively.

As observed in table 5 item 4, teachers and respondents were asked about their view whether the school supervision assist teachers in the implementation of new curriculum. Consequently, $93(51.1 \%)$ of the teachers and $27(50.0 \%)$ supervisors reveal that school supervisors failed to practice the stated activity. The chi-square computed at 0.5 level of significance with two degree of freedom become $\chi^{2}=0.045$, which is lower than the 
table value $\chi^{2}=5.991$. This implies that there is no significant difference among the responses of two groups.

A chi-square test was calculated to check whether the opinion difference exists among the two group respondents, the computed chi-square value $\mathrm{x}^{2}=0.992$, and $\mathrm{x}^{2}=0.045$, for item 3 and 4 respectively, are less than the table value $\mathrm{x}^{2}=5.991$ at 0.05 significant level with two degree of freedom. This means that there is no a significant difference between the response of two group respondents.

The data obtained from the interviewed principals and secondary school supervisors revealed that instructional supervisors seldom visit classroom while newly employed teachers are teaching for 10-15 minutes, later hold meeting in group so as to discuss highlights about performances of instruction. As the interview participants, holding conference with individual teachers would be difficult to address them effectively because the numbers of teachers in the schools are large.

Regarding supervisors effort in facilitating teachers-parent partnership 88 (48.4\%) teaches and $32(59.3 \%)$ totally $120(51.9 \%)$ respondents disagreed that supervisors effort was suggested to be ineffective. As can be shown from the table 6 above, the computed chi-square value of item $\chi^{2}=4.603$ is lower than the table value $\chi^{2}=5.991$ at a significant level of 0.05 with two degree of freedom. Hence, there is no significant difference in response of the two groups.

Depending on the above finding the researcher concluded that, instructional supervision in secondary schools of Bale zone have not contributed much for teachers' professional development.

\subsubsection{Major factors affecting instructional supervision practice}

Table6. Respondents views Major factors affecting instructional supervision practice

\begin{tabular}{|c|c|c|c|c|c|c|c|c|c|c|c|}
\hline \multirow[t]{3}{*}{ No } & \multirow[t]{3}{*}{ Items } & \multirow[t]{3}{*}{ Respondents } & \multicolumn{8}{|c|}{ Responses } & \multirow{3}{*}{$\begin{array}{l}\text { Computed } \\
\chi^{2}\end{array}$} \\
\hline & & & \multicolumn{2}{|c|}{ Disagree } & \multicolumn{2}{|c|}{ Undecided } & \multicolumn{2}{|c|}{ Agree } & \multicolumn{2}{|c|}{ Total } & \\
\hline & & & No & $\%$ & No & $\%$ & No & $\%$ & No & $\%$ & \\
\hline \multirow[t]{5}{*}{1} & \multirow{5}{*}{$\begin{array}{l}\text { Teachers perceive } \\
\text { supervision as a fault } \\
\text { finding than helping } \\
\text { activity. }\end{array}$} & Teacher & 61 & 33.5 & 23 & 12.6 & 98 & 53.9 & $18 \overline{2}$ & 100 & \multirow[t]{5}{*}{4.686} \\
\hline & & Supervision & 12 & 22.2 & 4 & 7.4 & 38 & 70.4 & 54 & 100 & \\
\hline & & Total & 73 & 30.9 & 27 & 11.5 & 136 & 59.6 & 236 & 100 & \\
\hline & & Supervision & 28 & 51.9 & 8 & 14.8 & 18 & 33.3 & 54 & 100 & \\
\hline & & Total & 130 & 55.1 & 17 & 7.2 & 89 & 37.7 & 236 & 100 & \\
\hline \multirow[t]{3}{*}{2} & \multirow{3}{*}{$\begin{array}{lr}\text { Teachers } & \text { perceive } \\
\text { supervisors } \\
\text { incompetent to the } \\
\text { position. }\end{array}$} & Teacher & 70 & 38.5 & 14 & 7.7 & 98 & 53.8 & 182 & 100 & \multirow[t]{3}{*}{3.919} \\
\hline & & Supervision & 20 & 37.0 & 9 & 16.7 & 25 & 46.3 & 54 & 100 & \\
\hline & & Total & 90 & 38.1 & 23 & 9.8 & 123 & 52.1 & 236 & 100 & \\
\hline \multirow[t]{3}{*}{3} & \multirow{3}{*}{$\begin{array}{lr}\text { Teachers } & \text { perceive } \\
\text { supervision a means to } \\
\text { promote } & \text { teachers } \\
\text { autonomy. } & \\
\end{array}$} & Teacher & 109 & 59.9 & 19 & 10.4 & 54 & 29.7 & 182 & 100 & \multirow[t]{3}{*}{0.696} \\
\hline & & Supervision & 29 & 53.7 & 7 & 13.0 & 18 & 33.3 & 54 & 100 & \\
\hline & & Total & 138 & 58.5 & 26 & 11.0 & 72 & 31.5 & 236 & 100 & \\
\hline \multirow[t]{3}{*}{4} & \multirow{3}{*}{$\begin{array}{l}\text { Teachers perceive } \\
\text { instructional } \\
\text { supervision preferable } \\
\text { means of teachers } \\
\text { supportive }\end{array}$} & Teacher & 70 & 38.5 & 35 & 19.2 & 77 & 42.3 & 182 & 100 & \multirow[t]{3}{*}{0.525} \\
\hline & & Supervision & 18 & 33.3 & 12 & 22.2 & 24 & 44.4 & 54 & 100 & \\
\hline & & Total & 88 & 37.3 & 47 & 19.9 & 101 & 42.8 & 236 & 100 & \\
\hline \multirow[t]{3}{*}{5} & \multirow{3}{*}{$\begin{array}{l}\text { Supervisors are well } \\
\text { trained in instructional } \\
\text { supervision to give } \\
\text { support to teachers }\end{array}$} & Teacher & 98 & 53.8 & 18 & 9.9 & 66 & 36.3 & 182 & 100 & \multirow[t]{3}{*}{1.331} \\
\hline & & Supervisor & 33 & 61.1 & 6 & 11.1 & 15 & 27.8 & 54 & 100 & \\
\hline & & Total & 131 & 55.5 & 24 & 10.2 & 81 & 34.3 & 236 & 100 & \\
\hline \multirow[t]{3}{*}{6} & \multirow{3}{*}{$\begin{array}{l}\text { Workshops, seminars, } \\
\text { trainings } \\
\text { arranged were } \\
\text { supervisors to upgrade } \\
\text { their advisory status. }\end{array}$} & Teacher & 112 & 61.5 & 19 & 10.4 & 51 & 28.0 & 182 & 100 & \multirow[t]{3}{*}{2.327} \\
\hline & & Supervisor & 36 & 66.7 & 8 & 14.8 & 10 & 18.5 & 54 & 100 & \\
\hline & & Total & 148 & 62.7 & 27 & 11.4 & 61 & 25.9 & 236 & 100 & \\
\hline \multirow[t]{3}{*}{7} & \multirow{3}{*}{$\begin{array}{lr}\text { Experience } & \text { sharing } \\
\text { session has } & \text { been } \\
\text { organized } & \text { for } \\
\text { instructional } & \\
\text { supervisors. } & \\
\end{array}$} & Teacher & 91 & 50.0 & 18 & 9.9 & 73 & 40.1 & 182 & 100 & \multirow[t]{3}{*}{5.938} \\
\hline & & Supervisor & 34 & 63.0 & 8 & 14.8 & 12 & 22.2 & 54 & 100 & \\
\hline & & Total & 125 & 53.0 & 26 & 11.0 & 85 & 36.0 & 236 & 100 & \\
\hline
\end{tabular}

The table value $\chi^{2}=5.991$ at 0.05 significant levels with four degrees of freedom 
As shown in table 6 of item 1, teacher and supervisor respondent asked whether or not teachers perceive supervision as a fault finding rather than helping activity. Accordingly, totally 136 (59.6\%) respondents agreed on the existence of such perception.

As can be observed in table 6 item 2, the respondents were asked whether or not teachers perceive supervisors as in competent to the position. In light of these, majority 98 (53.9\%) teachers and $25(46.3 \%)$ supervisors totally $123(52.1 \%)$ respondents agreed on the supervisors' incompetence to the position.

As indicated in item 3 of table 6, the majority, $109(59.9 \%)$ and $29(53.7 \%)$ teacher and supervisor respondents respectively disagreed on teachers perception is positive to the contribution of supervisors to promote teacher autonomy.

A chi-square test was calculated to check whether the opinion difference exists among the two groups of respondents. Accordingly, the computed chi-square values of item 1, 2 and 3 in the above table are less than the table value $\chi^{2}=5.991$ at 0.05 significant levels with two degrees of freedom. This implies that there is no significant difference between the responses of the two groups of respondents.

Respondents requested whether instructional supervision is preferable for teachers' supportive service or not. In respect to this, the majority $77(42.3 \%)$ of teachers and 24 (44.4\%) of supervisors totally 101 (42.8\%) respondents asserted their agreement. The computed chi-square indicated no significant difference between the views of two groups.

In light of the forgoing analysis, Jhonson and Johnson (2002) teachers have a trust their supervisors to develop positive views towards school based supervision and instruction. When teachers cannot trust their supervisors their ability to deliver quality instruction is seriously impaired. Thus, teachers' perception of supervision is valuable to improve instruction.

As indicated in Table (6 item5), the respondents were asked whether instructional supervisors were well trained in supervision to give technical and other support to teachers. In light with this, majority, $98(53.8 \%)$ of the teachers and $33(61.1 \%)$ of the supervisors totally $131(55.5 \%)$ respondents said that the activity was not practiced. Therefore, the data show that supervisors were not well trained in supervision to support teachers. Teachers and supervisor respondents were also asked their view whether or not workshops, seminars and trainings were arranged for instructional supervisors to upgrade their advisory status.

As shown under item 6, table 6, $112(61.5 \%)$ teachers and $36(66.7 \%)$ supervisors totally $148(62.7 \%)$ respondents revealed the non-existence of workshops, seminars and short term trainings for supervisors to upgrade their skill.

Table 6, item 7 illustrates that $91(50.0 \%)$ teachers and 34 (63.0\%) supervisor respondents reported that experience sharing session has not been organized for instructional supervisors. The computed chi-square values $\chi^{2}=1.331$ and $x^{2}=2.327$ and $\chi^{2}=5.938$ for items 1,2 and 3 respectively was found to be less than the table value $\chi^{2}=5.991$ with two degrees of freedom at the 0.05 level of significant. This implies that there is no statistically different on the response of the two groups of respondents.

Furthermore, the response of the interview held with school principals, and secondary school supervisors also revealed that there was no any attempt made to train the instructional supervisors in the secondary school. Principals and secondary school supervisors also made little attempt to support instructional supervisors.

Hence based on the result of the chi-square test and the data gained from interview, it is possible to conclude that instructional supervisors in secondary schools of Bale Zone were made to be involved in complex task of supervision,impeded by absence of competent supervisors, and negative perception of teachers towards school supervisors and without having any prior training. Thus, factors mentioned above did affect the proper practice of instructional supervision in the secondary schools of areas under study.

\section{SUMMARY, CONCLUSIONS AND RECOMMENDATIONS}

Based on the review of literature and analysis of the data, the study came up with the following findings:

- The practice of self-directed supervision approaches by teachers in identifying need for improvement and plan for improvement was effective but, teachers do not have freedom to plan the way they like.

- The practice of inquiry-based supervision approaches for teachers' professional development was not sufficient.

- The majority of the respondents indicated that the clinical supervision approach were not made mutual agreement and discuss on the content, objective and method of teaching with teachers on the lesson observed before classroom observation; they were not use observation instrument efficiently and not give sufficient time to observe the lesson most of the time they were inter the class at the middle or end of the lesson. Therefore they were not capable enough to utilize pre-class observation, class observation and post observation conference.

- Most of the respondents responded that clinical supervision approaches were preferable for their professional development. 
- The supervision support was focused only on assisting the newly employed teachers and supervisors lacked the necessary knowledge and skill to conduct supervisory activities.

- Regarding the supervisory practice in facilitating professional development of teachers through mentoring programs and collegial or peer coaching techniques of supervision, the majority of respondents agreed that the practices were unsatisfactory

- Furthermore, the majority of respondents reported that teachers were not encouraged to undertake joint planning of experience sharing programs on the local school context.

- The finding of the study revealed that training programs organized at school level were found in effective with regard to focuses towards achieving continuous professional growth of teachers. The reason behind for the ineffectiveness of the practice as revealed by the interview were supervisors poor competence and ignorant in organizing training programs, and supervisors full engagement in teaching works and left their supervisory tasks.

- The majority of the respondents confirmed that instructional supervisors were not arranging and promoting situations conducive to instructional improvement

- The study showed that instructional supervisors were not capable enough to shoulder responsibilities of facilitating the supply of instructional materials to teachers, as well as arrange programs to solve instructional problems

- The majority of respondents asserted that instructional supervisors failed to help teachers to be efficient in identifying and in solving instructional problems to enhance instructional effectiveness.

- The findings showed that instructional supervisors failed to assist teachers, in implementing the new curriculum and in evaluating the existing curriculum so as to take corrective measure.

- The findings of the study confirmed that the supervisory practice of instructional supervisors did not serve as advice means to assist teachers in the preparation and provision of teaching manuals and materials, and in facilitating teachers and parents' partnership.

- Majority of respondents indicated that the existence of factors that hinder the proper implementation of instructional supervision, such as: teachers who had negative reaction towards supervisory service of the school; lack of training, workshops, seminars and experience sharing session for instructional supervisors; failure to provide in service training opportunity to teachers; lack of adequate support like some guidelines and checklists as well as shortage of budget to conduct supervision; shortage of experienced supervisory personnel; big teaching (work) load of instructional supervisors and assigning small number instructional supervisors.

- Moreover the majority of the respondents confirmed that no strong attempts were made by instructional supervision committee members, the school and woreda education officials in solving the above mentioned factors.

\subsection{Conclusions}

Based on the above major findings of the study, the following conclusions are made.

The findings of the study noted that the clinical supervision were not capable enough to utilize the three procedures of classroom observation. Moreover, the findings showed that pre-class observation and post observation conference were held rarely in a department level. As a result, the practice failed to enhance teachers' professional development.

As the data from the interview and questionnaire indicated clinical supervision approach preferable for teachers' professional development. There for we can concluded that clinical supervision approach is the better way of teachers' professional development in addition to other approaches if it is practiced properly.

Most of instructional supervisors were not aware of the responsibility they had for professional development of teaches, and failed to play their role in creating conducive environment to bring professional competence of teachers.

Instructional supervision was not adequately practiced in secondary schools of Bale zone.

Instructional supervision service and professional support provided to teachers in secondary school of Bale zone was not adequate.

\subsection{Recommendations}

It is advisable for regional education bureau, zonal education office, woreda education office and different stakeholders to work collaboratively for the effectiveness of the practices of different instructional supervision approaches for teachers' professional development. By giving training, experience sharing and other capacity building programs for instructional supervisors for the effectiveness of the practice.

Different instructional supervision approaches enhances teachers professional development when it is practiced properly. Therefore, instructional supervisors and teachers should motivated and trained in conducting 
different supervisory approaches by assessing their teaching, doing action research on the problem they faced and to work collaboratively to solve their problem.

As the data from the respondents indicated many respondents prefer clinical supervision approach. There for different educational official must give training and develop the concept of instructional supervisors on the implementation of the approach.

Instructional supervisors are required to give emphasis to the creation of awareness in teachers; have to reach an agreement with teachers on purpose and procedures of classroom observation, and have to conduct all classroom observation procedures in a planned manner.

The school and woreda education offices made strong effort to improve the practices of in-service trainings, induction or monitoring and collegial supervision to facilitate teachers' professional development.

The study revealed that the effectiveness of instructional supervisory practice in the secondary schools of Bale zone is hindered by many factors. Therefore, to alleviate/solve these problems all concerned bodies (the OREB, ZEB, WEB and school officials in collaboration with NGOs) are recommended to take the following measures.

Short-term refreshment trainings through seminars, workshops or through discussion forums should be organized and implemented for instructional supervisors and teachers. Trainings should be plan and implemented effectively so as to help the participants to develop their skill and knowledge of instructional supervision.

Experience sharing programs regarding instructional supervision within school and across secondary schools in the zone should be design and implemented by joint efforts of schools, zone and woreda education offices. For instance, by assigning a yearly education week the schools can demonstrate their best experience and improvements related to the practice of supervision so as to enable others share experiences.

Adequate budget needs to be allocated for instructional supervisors so as to improve the supervisory service at school. Instructional supervision committee members should be free from routine tasks and reduced their teaching load to a maximum of 10 periods per week in line with the instructional supervision manual of the region. This helped them to render enough time for organizing and performing supervisory tasks.

The members of instructional supervision are too few as compared to the increasing number of teachers. The team members are shouldering burden beyond their capacity. Thus, in order to provide adequate supervisory support to teachers the number of instructional supervisors in school should be assigned as stated in the guideline of instructional supervision manual of the region. (12 supervisors for teaching stuff of 61 and above).

\section{References}

Aggarwal, J. 1985. Theory and Principles of Education: Philosophical and Sociological Bases of Education. New Delhi: Vikas Publishing House Pvt. Ltd.

Ahmed, M. 1998. Trends in School Supervision for Teacher Development:a Proposal for Pakistan. Paris: UNESCO. Retrieved on November 28/2012 from http://unesdoc.unesco.org/images.pdf

AtikltDeasta. 2008. The Status of School in Built Instructional Supervision in Government Secondary Schools of Mekele Zone. Addis Ababa University (Unpublished MA thesis).

Carron, G.A. De Grauwe and R. Govinda. 1998. Supervision and Support Service in Asia. A comparative analysis.Paris NUESCO/NESCO/International Institute for Educational Planning.

ChanyalewWoldGegebriel. 2005. The Practice and Problems of Instructional Supervision in Secondary Schools of Hadya Zone. Addis Ababa University (Unpublished MA Thesis).

Dull, L.Loyd, W. 1981. Supervision: School Leadership Handbook. Ohio Charles E.MerrilPub.C.

Ebmeier, H., and Nicklaus, J. 1999. The impact of peer and principal collaborative supervision on teachers' trust, commitment, desire for collaboration, and efficacy.Journal of Curriculum and Supervision, 14(4):351-378.

Elmore, R. F. 2002. Bridging the gap between standards and achievement: the imperative for professional development in education.Paper for Albert Shanker Institute.

Garet M., Potter, A.Desimonel.,Birman B., and K.S. Yoom 2001. What makes professional development effective? Results from a national sample of teachers.American Educational Research Journal. Vol. 38(4): 915-945.

Haile Abbay. 2006. Practices and Problem of School-Based Supervision in Selected Secondary Schools of Central Zone of Tigray. AAU (Unpublished MA Thesis)

Haileselassie W/gerima. 1997. Educational Supervision Teaching Material. Addis Ababa University, Faculty of Education.

Leeper, Robert Rosborogh.1969. Supervision Emerging Profession and Current Development. Washington NEA.

Lucio, William, H., and John, D. McNeil. 1979. Supervision: A Synthesis of Thought and Action $3^{\text {rd }}$ edition. New York:McGraw-Hill.

Lue, E. 2004.School and Cluster-Based Teacher Professional Development: Bringing Teacher learning to the School-Retrieved on September 10, 2012 from http://www.equip123- net/docs/EQl working paper/pdf. 
McBridge. 1996. Teachers Education Policy: Some Issues Arising from Research and Practice: London Falmer Press.

MoE. 1994. Supervision Manual. Addis Ababa.

MoE. 1994. The education and Training Policy of the Federal Republic of Ethiopia: Addis Ababa, Ministry of Education.

MoE. 1995. Supervision Manual. Addis Ababa. Minster of Education.

MoE. 2002. Education Sector Development Program II. Addis Ababa.

Mohanty, B. 1990.School Administration and Supervision. New Delhi: Deep and Deep Publications.

Montee, Sullieean. 1990. Applied Social Research Tools for the Human Services.London, UK: Printer Publishers. Sudman.

OREB.2007.Maanwallii Adeemasa Hoji Kenna Degarsa Ogummaa fi Hordoffii Barnootaa. Garee JBAH BBO:Finfinee. 